DENISE MOURA

Noite de

autógrafos do

livro Velhas

Fazendas do Vale do Paraíba.

Roseiras, SP, I 975

\title{
DENISE MOURA
}

é doutoranda do

Departamento de

História da FFLCH-USP

e autora de Saindo das

Sombras: Homens Livres

e o Declínio do

Escravismo (CMU-

Unicamp/Fapesp).

"Já apsendi bá muita tempa que nãa sei narsar simplesmente as fatos. Tenbo necessidade de assumi-los, vivenda-as. Assim, nãa distinga a que é da passada an da presente - eles wãa se contem?" (Jarge Andrade, Labirinto, 1978).
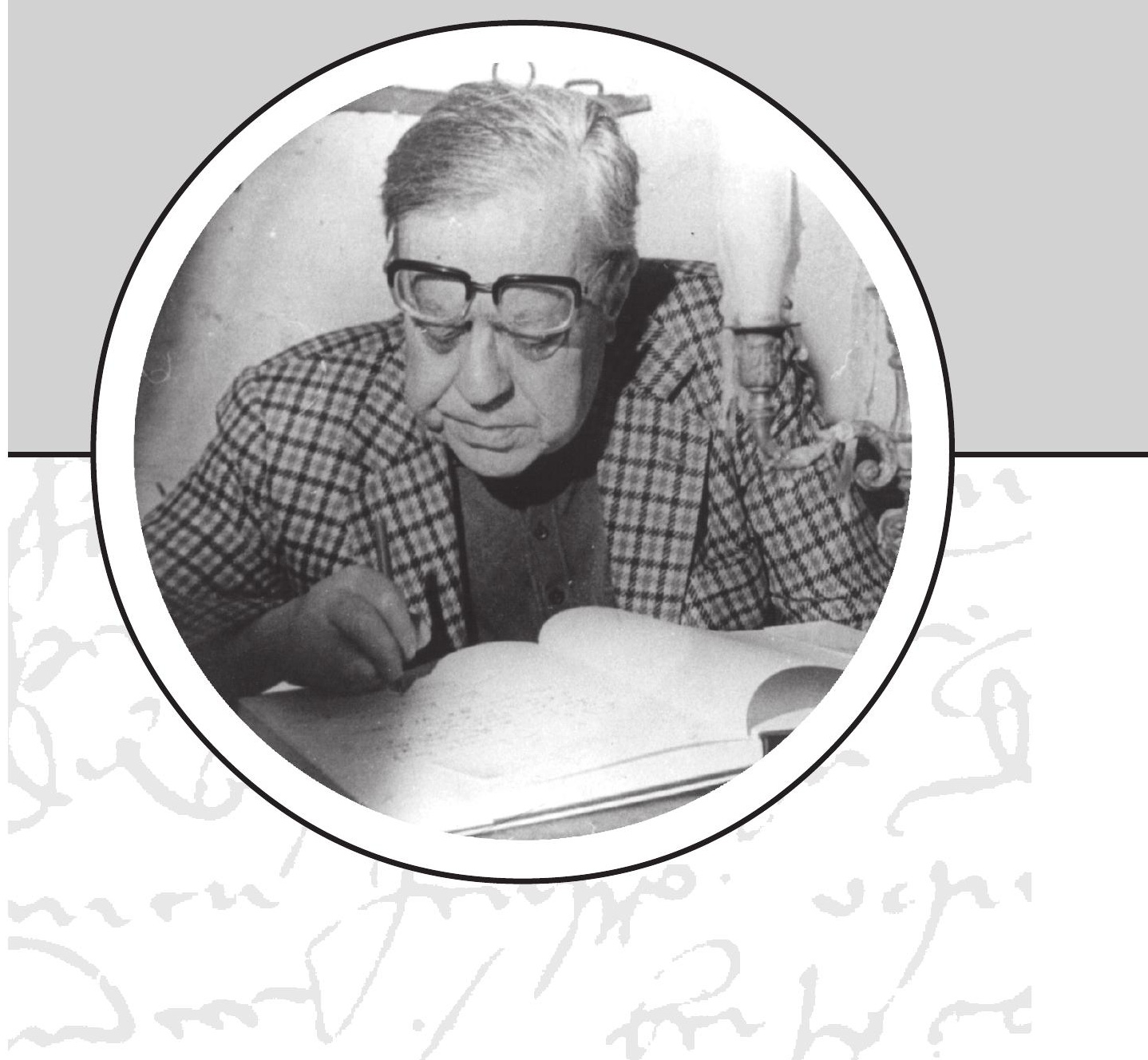


\section{Sérgio Buarque}
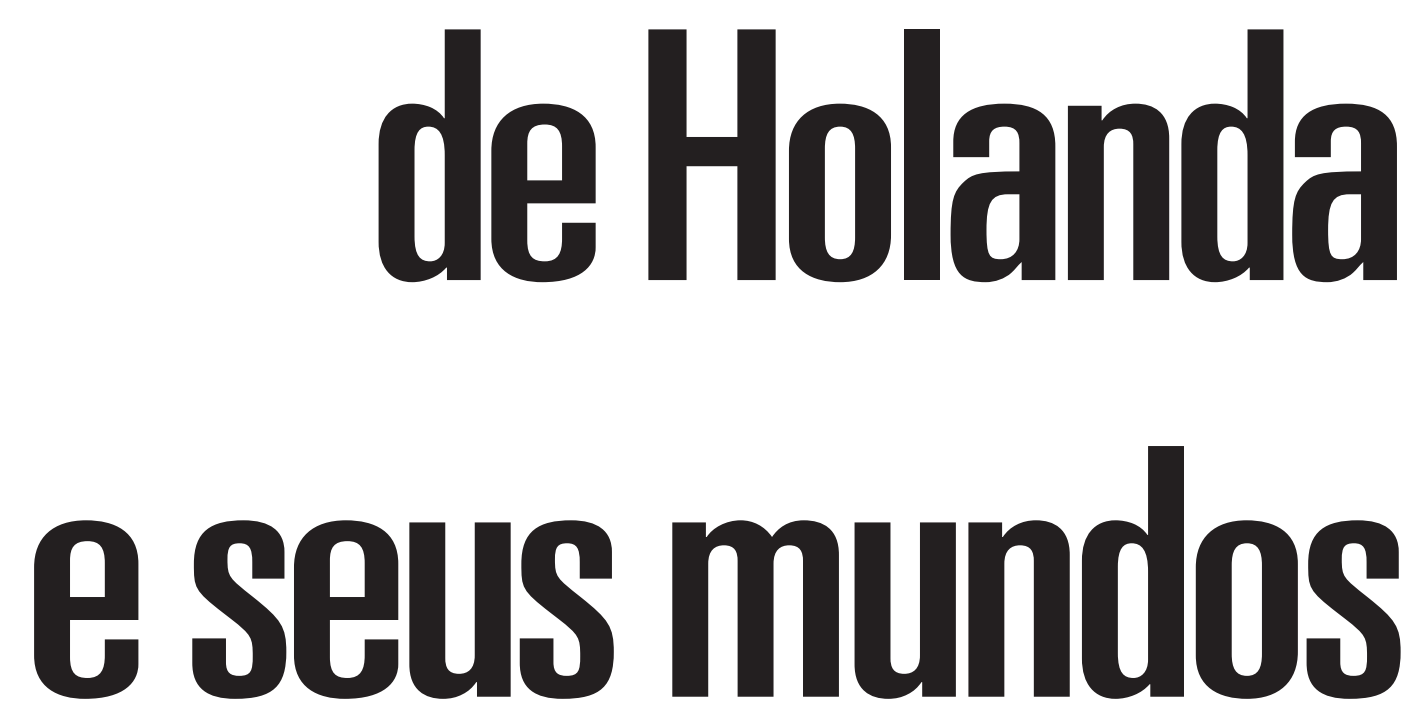

desvelados 
oi como escritor já consagrado por Raízes do Brasil (1936), Monções (1945) e Caminhos e Fronteiras (1957) que Sérgio Buarque de Holanda ingressou em 1958 na Universidade de São Paulo, na condição de professor catedrático de História da Civilização Brasileira do Departamento de História da Faculdade de Filosofia. A obra-prima Visão do Paraíso (1958), estudo magistral sobre a mentalidade portuguesa e o mito do paraíso terrestre em suas conexões com a cultura, a sociedade e os prelúdios da colonização do Brasil, viria referendar, no âmbito acadêmico, uma condição já plenamente reconhecida no meio intelectual que pulsava ao redor dos muros da universidade (1).

Os estudos desses anos expressam o pesquisador exaustivo que foi Sérgio Buarque, sua preocupação em dialogar com documentação vasta, variada e original sem cercear suas múltiplas possibilidades em modelos teóricos fechados ou métodos científicos preestabelecidos. Ao assumir as realidades históricas de que tratou, ao invés de simplesmente analisá-las, desenvolveu um estilo narrativo que lhe permitiu percorrê-las com intimidade.

É assim que parece fazer o movimento do sertanista de desbravar o território em direção a Minas Gerais e Goiás, conhecendo e descrevendo pormenorizadamente os modos e técnicas adventícias e indígenas das bandeiras e monções.

Ao tratar com detalhes minuciosos e densos da pelota ou da canoa de casca, tipos de embarcações que dilataram os caminhos fluviais em direção a Goiás, da pisadura de índios e adventícios ao cruzar os sertões ou dos expedientes empregados pelos do planalto para lidar com as hostilidades e as benevolências do meio natural, revelou um esforço de interiorização ao mundo colonial paulista.

Sua prática de historiador faz o difícil exercício de fundir-se ao período que evoca, habitando-o, comungando com os seres suas experiências de viabilização da vida numa terra generosa, mas impiedosa, como era a dos primeiros tempos da colônia.
Assim, o método em que se apóia não parece ser o do estudioso que observa e tira conclusões do seu objeto, mas daquele que o incorpora, compartilhando e usando com maestria expressões de época e de sua gente. Era uma maneira de se aproximar daqueles que no passado mourejaram com cangalha nas costas, ceifaram picadas na mata densa, arriscaram-se galgando penhascos escorregadios, pelejaram com febres, flechas, feras e atravessaram rios com água à metade do corpo (2).

Esse esforço aproximou-o também das disposições de espírito dos seres, ao captar as emoções daqueles que devassaram os caminhos fluviais para Cuiabá. Para compensarem o tempo e a monotonia da viagem de volta para o povoado, procuravam formas familiares da terra natal na barra do Tietê, manifestando grande gritaria de contentamento (3).

O estilo de Sérgio Buarque de Holanda, ao enveredar-se pelo mundo colonial paulista, envolveu, portanto, uma narrativa de interiorização, humanizadora dos sujeitos históricos e parece reatar nossos elos com a terra, com nossas raízes rurais e culturais, reelaboradas no correr do tempo e nos enfrentamentos cotidianos.

A partir da década de 60 iniciou a organização da obra coletiva História Geral da Civilização Brasileira, participando com vários ensaios que apontavam seus novos rumos de pesquisa. Tratava-se, naquele momento, de acompanhar as conjunturas sociais, econômicas, políticas e demográficas, captar as contradições políticas do regime monárquico que se instaurara no país após a independência e as persistências coloniais no tecido histórico, social, cultural e político brasileiro.

No estudo de vários aspectos ligados à vida no Império, a sensibilidade aguçada para recompor processos sociais mais amplos à luz de particularidades deixou o caminho aberto para a renovação da historiografia sobre esse período. É o que parece apontar um ensaio pouco citado como "As Colônias de Parceria", publicado em 1967 na História Geral da Civilização Brasileira, mas já esboçado na intro- 
dução de 1941 ao livro de Thomas Davatz, mentor do motim de colonos suíços na colônia de Ibicaba. Ao palmilhar o mundo cafeeiro paulista através dessa experiência particular e pioneira do senador José Vergueiro, Sérgio Buarque abriu caminhos que conduzem aos meandros da vida social e cotidiana desse período de declínio do regime escravista.

As colônias eram propriedades agrícolas dedicadas ao cultivo do café e a parceria envolvia o sistema de trabalho e remuneração. Ao colono parceiro cabia uma porcentagem do café colhido e o direito de plantar em uma porção de terra verduras, frutas e legumes para sustento e pequeno comércio. O sistema de parceria envolvia, assim, a combinação entre remuneração e possibilidade de produção independente.

Em 1857, as primeiras famílias suíças aportaram em Santos e, extenuadas pela longa travessia do Atlântico, concluíram o resto do percurso por terra até a colônia do senador, em Limeira. Apreensivos e tomados pela expectativa da chegada numa nova terra, só o correr do tempo lhes revelaria os vícios de um regime que adotavam: o avolumar das dívidas de viagem e estabelecimento inicial, o autoritarismo dos diretores das colônias, a incompreensão dos cálculos de seus ganhos, a insistente sensação de estar sendo lesado e as precárias condições materiais a que se viam sujeitos. Tal situação favoreceu a eclosão da sedição de 24 de setembro de 1866, conhecida como a revolta dos parceiros.

Muitos dos estudos anteriores de Sérgio Buarque ecoam sutilmente nesse ensaio, enfeixando indícios relevantes para o estudo das tensões e entrosamentos entre os seres da época. Em seu percurso pelo cotidiano do mundo cafeeiro paulista, chama a atenção para o espírito discreto e contido dos senhores em lidar com a crise do regime escravista que se anunciava e suas formas de convivência com as personagens miúdas do dia-a-dia.

A partir da sua leitura é possível acompanhar persistências coloniais em iniciativas longamente tidas como símbolo de avanço e modernidade, desvelando o estreitamento entre homens que outrora devassaram os sertões em busca de metais preciosos e os que nesse momento interiorizavam-se nesse mesmo sertão, dilatando as forças do progresso, pois entendia que o "bandeirismo do ouro e o bandeirismo do café" pertenciam a "uma só família" (4).

Seguindo as trilhas desse ensaio, o leitor defronta-se com a possibilidade de, desde os ensaios de colonização realizados pelo governo, ter o forasteiro do norte e centro da Europa se ressentido da incapacidade de travar um diálogo com a geografia e a ecologia das terras brasileiras, algo que se mostrou fundamental no povoamento paulista e revelou nos forasteiros ibéricos seu potencial de gerar formas criativas de existência em meio à apropriação da adversidade e dos imprevistos oferecidos pelas asperezas do meio (5). Essa inaptidão em ajustar-se ao ambiente natural fez com que colonos açoritas não chegassem a fincar pé em Casa Branca, amedrontados com o tamanho das árvores que teriam de derrubar (6). Iludidos com a riqueza das terras, muitos europeus acreditavam que poderiam amealhar muitas vantagens com sua uberdade, mas o entranhamento no mato mostrou a teimosia de uma vegetação que só os métodos da agricultura indígena eram capazes de amansar.

Chegavam os colonos a alarmarem-se com as inúmeras queimadas que devoravam os roçados, fazendo subir nuvens de fumaça que ofuscavam o sol, mesmo em dia muito claro. $\mathrm{O}$ trato da terra visando preservar-lhe o vigor, conforme muitos tentaram praticar, mostrou-se ineficaz, principalmente diante do hábito tradicional de gastar o solo de cultura em plantas e fogos repetidos. O próprio senador José Vergueiro "mandava derrubar as matas, aproveitava as terras durante alguns anos para outras comodidades, e deixava crescerem capoeiras; só ao cabo disso fazia plantar as primeiras mudas de café", expressando o quanto técnicas agrícolas tradicionais tiranizaram por longo tempo as práticas dos homens, demorando para se dissiparem (7).

Essa dissonância com o meio revelou-

\footnotetext{
4 "Prefácio", in Thomas Davatz, Memórias de um Colono no Brasil (1850), tradução de Sérgio Buarque de Holanda São Paulo/Belo Horizonte, Edusp/Itatiaia, 1980, p. 33.

5 Sérgio Buarque de Holanda, Caminhos e Fronteiras, op. cit.

6 Saint-Hilaire citado em "Prefácio", op. cit., p. 16

7 Idem, ibidem
} 
se na pouca habilidade do colono europeu em lidar com o clima e a vegetação dos trópicos, no medo de expor a cabeça descoberta ao sol, quase não suportando andar descalço sob a terra quente, que acreditava e dizia queimar os pregos das solas dos sapatos, desprendendo-as à imposição do calor. As florestas virgens brasileiras seduziam pela opulência, mas qual fruto proibido intensamente desejado prenunciavam martírios. Outra praga a acentuar-lhe os sofrimentos era o bicho-de-pé. Intrometia-se pelas plantas dos pés, principalmente sob as unhas e acomodava-se à carne, aninhando seus ovos. Se não fosse extraído logo, com um alfinete, gerava "protuberâncias do tamanho de uma caroço de cereja" (8).

Esse mesmo bicho-de-pé seria razão de gozo para sertanistas e trabalhadores dos tempos do café. Destemidos da quentura da terra, andavam continuamente descalços e assim se embrenhavam pelo mato, preferindo extrair o bicho das unhas a evitá-los, dado o entorpecimento dos sentidos que a sua presença e extração causavam (9).

Principalmente Caminhos e Fronteiras e Monções evocam a interpenetração das forças da natureza e dos seres como substrato fundamental na constituição da sociedade e da cultura paulista, levando

8 Thomas Davatz, op. cit., pp. 55-6 e 78 .

9 Sérgio Buarque de Holanda, Caminhos e Fronteiras, op. cit., pp. 102-3.

10 "Prefácio" ao livro de Thomas Davatz, op. cit., pp. 20-1.

I I Idem, ibidem, pp. 23-4.

12 Sérgio Buarque Holanda, "Colônias de Parceria", in História Geral da Civilização Brasileira (em colaboração com Pedro Moacyr Campos), 6e ed., São Paulo, Bertrand Brasil/Dife 1987, tomo II, vol. III, p. 246.

13 Idem, ibidem.

I 4 Idem, Visão do Paraíso, op. cit., especialmente o capítulo "Atenuações Plausíveis".

I5 Maria Odila Leite da Silva Dias (org.), Sérgio Buarque de Holanda, São Paulo, Ática, 1985 (Col. Grandes Cientistas Sociais, n. 51 ), p. 34. transitório", uma maneira de atenuar os desajustamentos que o fim da escravidão poderia trazer (12).

Colocar homens do sul e centro da Europa, ombreando o trabalho nas fazendas com escravos, criaria uma fase intermediária da abolição, capaz de conter quadros de tensão desenfreados. Para alguns, já antes da independência, trazer imigrantes para torná-los parceiros parecia o "meio mais seguro de chegar-se à abolição do trabalho escravo, que [lhes] parecia coisa inevitável e próxima, sem uma catástrofre de proporções incalculáveis" (13). Esse espírito receoso de mudanças e contido nas ações inovadoras faz lembrar a sensibilidade portuguesa da conquista, mapeada em Visão do Paraíso: o apego exacerbado ao passado medieval e por isso mesmo o desafeiçoamento às especulações e aos vôos imaginativos do humanismo renascentista.

O mesmo espírito apaziguado em imagens miríficas, ao contrário dos castelhanos, fazia parte de uma maneira própria de apreender a realidade, apoiando-se em evidências e em imagens amplamente ambientadas aos seus referenciais, a ponto de os forasteiros ibéricos adotarem o hábito de nomear plantas e bichos com nomes familiares que prolongavam nos trópicos a mãe pátria (14).

A sensibilidade de Sérgio Buarque em alcançar "níveis de experiência e de consciência dos homens de outros tempos" (15) permitiu-lhe captar o impacto de valores tradicionais portugueses e seu pionerismo, sua personalidade voltada a cotidianizar o mito e os monstros imaginários. $\mathrm{O}$ forte apego luso à formas antiquadas revelou-se, por exemplo, na ação colonizadora propagada em colônias dispersas, compondo uma paisagem brasileira dos primeiros tempos mais de feitoria do que propriamente de colonização.

Na obra Visão do Paraíso, conforme já sensivelmente notado, o autor trabalhou com "as ambigüidades e as hesitações dos portugueses, que tergiversavam nas fímbrias do desconhecido, relutantes em enfrentar novidades". Era uma maneira também de acompanhar a mudança em meio às 


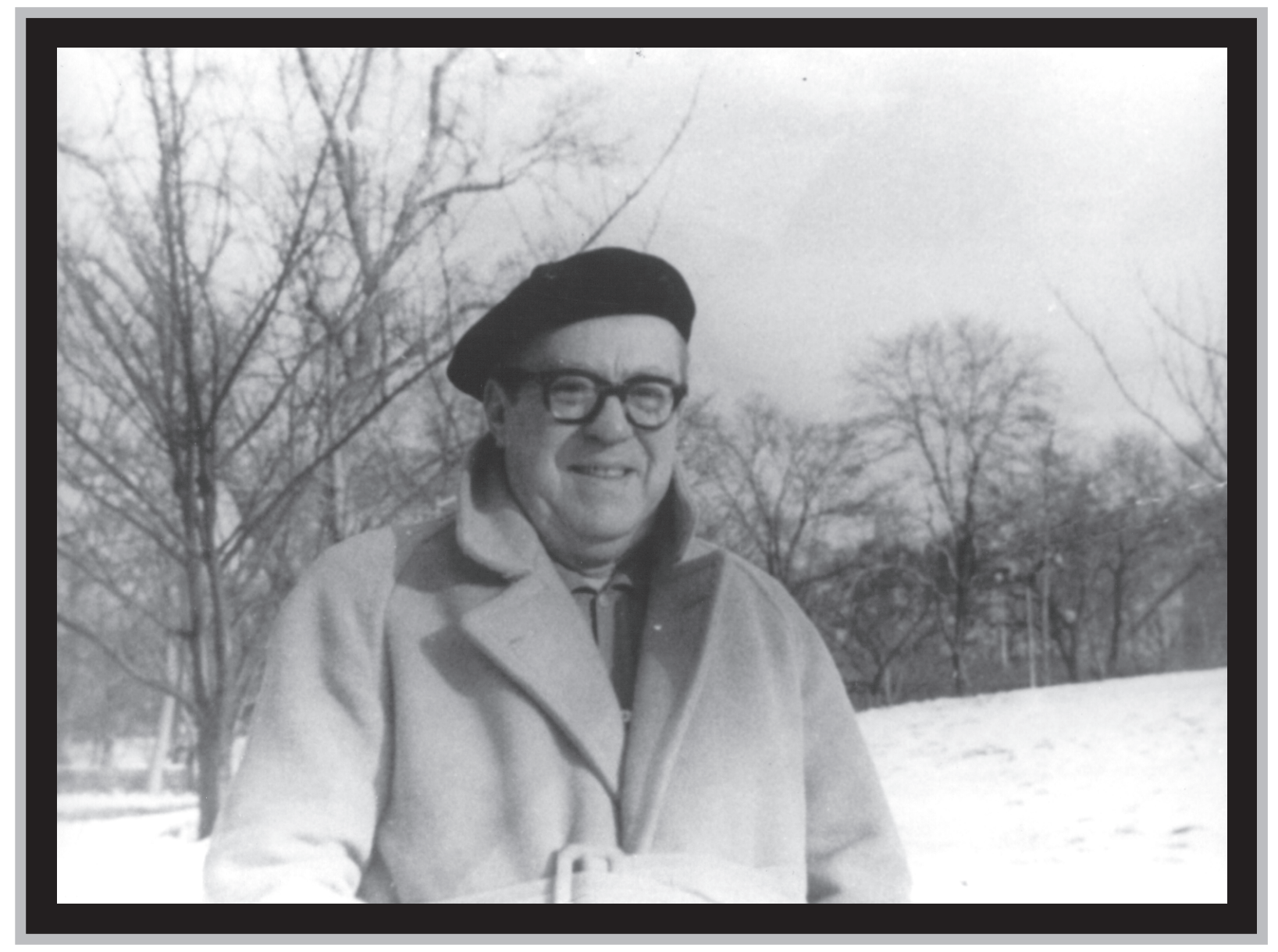

continuidades, identificando nas novas experiências persistências de formas tradicionais de existência (16).

Essa necessidade de apegar-se ao concreto, de apropriar-se do desconhecido e de manifestações vagas e traduzi-las em feições cotidianas aponta para uma personalidade ansiosa por manter o controle da situação com que se defronta. Mas essa resistência à novidade não redundou em condutas fixas, gerando um espírito moderado e contido, realista o suficiente para apropriar-se da adversidade e viabilizar a vida através dela. Tais traços podem ser vistos na vitória do português sobre um meio hostil ou na necessidade dos senhores do café em sentirem segurar nas mãos mudanças que se mostraram prementes no regime de trabalho já secular.

O mesmo temperamento comedido e relutante se revelaria na iniciativa dos fazendeiros em trazer imigrantes para a faina de suas lavouras, atenuando o impacto da novidade, de conseqüências talvez imprevisíveis, e suavizando a transição do trabalho escravo para o livre. Era também uma maneira, pelo menos aparente, de tornar a situação acessível aos sentidos e passível de ser controlada.

Essa despreocupação em repensar o regime de trabalho em vigor e inseri-lo efetivamente em novos moldes revela-se no fato de a maioria dos colonos trazidos pelo senador Vergueiro, comumente visto como personalidade inovadora, "só excepcionalmente procederem de zonas rurais". De um conjunto de 87 pretensos lavradores para trabalharem nas colônias de parceria de São Paulo, o viajante Tschudi constatou que apenas 13 vinham de origens rurais, sendo o restante operários de fábrica, sapateiros, carpinteiros, alfaiates, pedreiros e outros ofícios essencialmente urbanos (17). Não é admirável que o meio natural que encontraram nos trópicos lhes tenha parecido algo
Sérgio Buarque de Holanda no Central Park. Nova York, 1965

16 Idem, ibidem, pp. 32-40

17 Sérgio Buarque de Holanda, "Colônias de Parceria", op. cit., pp. 249-50. 
I 8 Idem, ibidem, p. 247

19 Idem, ibidem.

A família

Buarque de

Holanda invencível e a cidade se mostrasse cada vez mais promissora.

Ao apontar a inadequação dos imigrantes europeus às concepções de trabalho livre em vigor no Império, motivo de desajustamentos de toda ordem, Sérgio Buarque propõe a retomada da peculiar constituição sociocultural brasileira, erguida sobre valores de fidalguia, princípios orgânicos e sentimentais, que se reelaboraram no tempo e impregnaram todas as esferas sociais. Assim, a convivência tensa estabelecida com os primeiros colonos europeus que vieram "preparar a lavoura para receber sem graves perturbações a abolição da escravidão" esbarrou a todo momento com os "entraves criados por essa mentalidade e apoiados em longa tradição" (18).

Lembra o autor, a partir de leitura de cronistas conhecidos que, em 1839, alemães contratados para os serviços de construção de pontes e calçadas em Pernambuco de- sistiram da empreitada, tal o deboche a que se viram submetidos. Nos idos de 1870 , um lavrador de Bragança ofereceu boa recompensa a quem localizasse e trouxesse de volta um seu colono de origem germânica. O anúncio foi estampado no Correio Paulistano, com dizeres semelhantes aos que habitualmente advertiam sobre escravos fugidos (19). Aclimados de longa data na relação com cativos, dificilmente os senhores do café conceberiam prontamente em novos moldes a convivência com os imigrantes.

As formas de convivência tecidas desde a colônia na intimidade dos casarios e sítios, nas roças e no correr da sociabilidade diária parecem ter se constituído em modelo fixo para o cotidiano do trabalho no mundo rural paulista, resistente em se dissolver na relação com os colonos. Os princípios de vida doméstica, na qual o patriarca se desmanchava em esforços para agradar e proteger, mas também para tira-

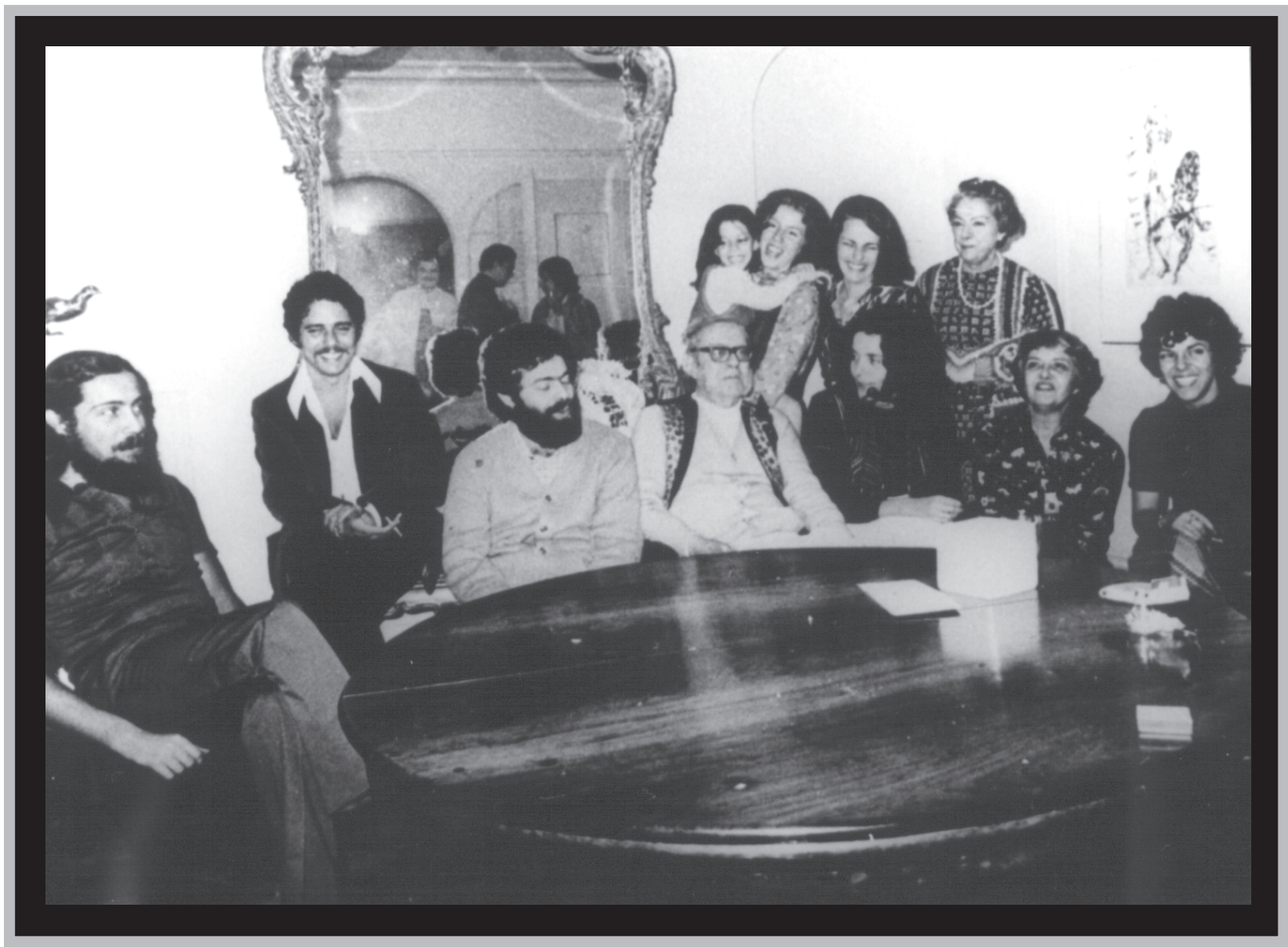


nizar e fazer prevalecer sua vontade, prosseguiram no Império, de forma que no interior das propriedades cafeeiras, senhores, seus familiares mais próximos, escravos e os livres de poucos cabedais mantinham-se ligados por uma cumplicidade afetiva e familial.

Ina von Binzer, uma educadora alemã que esteve no Brasil numa época em que o regime de trabalho escravo agonizava, surpreendeu-se com o trato que considerou exageradamente frouxo e afeiçoado na fazenda em que se hospedava. A caçula dos senhores costumava guardar um pouco de sobremesa para sua ama, lembrando sempre de pedir algo para seu "irmão-deleite". A filha mais velha, sabedora que sua velha aia apreciava enfeites, não media esforços para agradá-la com fitas multicor (20).

Também entre os escravos, mesmo quando desconhecidos, era hábito os mais moços chamarem os mais velhos de "tio", num gesto expresso de tornar a relação com o outro mais próxima do coração. Para a mesma educadora, pareciam feios e deselegantes os diminutivos e apelidos com os quais se dirigiam as pessoas umas às outras: sinhazinha, nhonhô, nhanhá, sinhara, nenê, nhonhozinho, bebê. Expressões comuns e que se desmanchavam em dengos e mimos. Na mesma fazenda, Ina disse nunca ter conhecido o verdadeiro nome de um empregado chamado João do Chapéu. O próprio fazendeiro assim o chamava e dessa maneira o fazia constar no livro de pagamentos (21).

A família patriarcal serviu de modelo para a vida política do país e para as relações entre governantes e governados, conforme escreveu Sérgio Buarque em Raízes do Brasil. O ensaio "Colônias de Parceria" viria indicar a influência desse mesmo princípio nas relações de trabalho, embaraçando os senhores no trato mais objetivo e pessoal com os colonos europeus. Estes, por sua vez, compartilhavam de uma incompreensão explicável a certas práticas fundamentais e hábitos gerados em lento e longo processo de ambientação.

Não faltaram imigrantes que souberam amoldar-se às formas de convivência doméstica, como foi o caso do diretor da fazenda Boa Vista, no município de Amparo, um jovem prussiano extremamente malvisto entre os colonos dado o seu modo áspero de tratamento. Aconselhado o fazendeiro a demiti-lo, este recusou-se suavemente, dizendo que o diretor ensinava seus filhos e à noite o distraía ao piano sendo "difícil substituir tal homem" (22). Casos como esses foram exceção.

Assim, o motim dos colonos suíços que teve lugar na colônia do senador Vergueiro não pode ser entendido exclusivamente à luz de critérios econômicos, como endividamento, sujeição aos valores pecuniários impostos pelos fazendeiros e desmandos. Na perspectiva de Sérgio Buarque, é preciso atentar para a permanência das formas tradicionais de convivência e, portanto, para a difícil integração entre colonos europeus.

Apontando caminhos de pesquisa a serem trilhados, "Colônias de Parceria" incita o leitor a imiscuir-se no correr dos dias do mundo cafeeiro paulista e a acompanhar diferentes situações que denotavam essa quase impossibilidade de diálogo. A diferença de idiomas era fator agravante, gerando situações confusas, como a de um fazendeiro que teve seu nome estampado na Revista Comercial de Santos sob acusação de intolerância religiosa e recusa em fornecer madeira suficiente para os caixões mortuários de seus colonos. Ao serem indagados, estes argumentaram "que o patrão não fala alemão e nós não sabemos o brasileiro, portanto ele não nos podia falar de tais cousas" (23).

O difícil diálogo entre princípios culturais distintos também endurecia as relações. Muitas vezes os próprios colonos incompreendiam modos de convivência que se afrouxavam em concessões mútuas. A permissão ampliada para que os colonos de uma fazenda se entregassem a seus folguedos aos domingos fez o viajante Tschudi defini-las como "verdadeiras orgias" que degeneravam em desentendimentos, chegando inclusive um português a apunhalar um brasileiro. Também enten-
20 Ina von Binzer, Os Meus Romanos: Alegrias e Tristezas de uma Educadorano Brasil trad. Alice Rossi e Luisita da Gama Cerqueira, 3a ed., Rio de Janeiro, Paz e Terra, 1982, p.

2I Idem, ibidem, p. 19

22 Johann Jakob von Tschudi, Viagens às Províncias do Rio de aneiro e São Paulo, trad. Eduardo de Lima Castro, São Paulo/Belo Horizonte, Edusp/ltatiaia, 1980, p. 169

23 Idem, ibidem, p. 167. 
dia que a generosidade alargada dos fazendeiros incitava os colonos a inúmeros excessos, tendo inclusive um deles tentado assaltar o fazendeiro e sua família em plena estrada, quando retornavam da cidade numa tarde de domingo (24).

Confundia os colonos europeus essa relação movediça, entranhada nos costumes da gente do país. De maneira explicável não souberam tecer as malhas das afetividades fundamentais que entorpeciam as tensões e desentendimentos. Basta pensar na própria maneira como os colonos europeus concebiam e organizavam a moradia, procurando criar uma situação de conforto, mesmo em meio à simplicidade material, que favorecia a sua permanência no interior da casa.

Tschudi considerava as moradias brasileiras extremamente desconfortáveis: “uma esteira no chão, para a família toda, um banco tosco a um canto, uma sela velha e uma espingarda dependurada em um prego; na cozinha algumas pedras faziam as vezes de fogão, e duas ou três tigelas"'(25). Dava ampla margem, assim, ao exercício das sociabilidades imprescindíveis nas vendas, nos caminhos e nas longas conversas, que reforçavam a vinculação orgânica e afetiva entre senhores de maiores recursos e aqueles que nasceram isentos de fortuna, favorecendo ajustes que atenuavam os conflitos.

Conclui Sérgio Buarque que um dos pontos mais vulneráveis do sistema de parceria foi a completa ausência de permissão de fiscalização da parte dos colonos sobre as operações realizadas entre a colheita do café e o ajuste de contas. "Todo o seu fundamento está no pressuposto, resíduo de concepções antiquadas, de uma absoluta confiança do colono no empresário" (26).

Diante dos freqüentes erros de cálculo dos diretores das colônias e da impossibilidade dos fazendeiros, mesmo bem intencionados, em explicar aos colonos as numerosas despesas que implicavam a lavoura de café, prorromperam queixas contínuas, às vezes exageradas e outras justas, como vieram comprovar muitas sindicâncias.

Esse princípio de confiança bastante acomodado à convivência com a gente do país prevaleceu nos seus ajustes de trabalho com os fazendeiros, atenuando tensões e impedindo explosões de ânimo mais violentas, como aconteceu com o motim de Ibicaba.

Nossas populações livres rurais, portanto, não se mantiveram segregadas no cenário de declínio do escravismo e de introdução forçada do trabalho livre nas fazendas de café paulistas. Ao lado de colonos europeus e escravos, viveram intensamente comprometidas com os fazendeiros, fortalecendo uma economia moral de fio de barba e empenho da palavra. Mais por rotina do que por resistência consciente às condições formais de trabalho, as pessoas livres e pobres do país mantiveram-se apegadas a princípios orgânicos e sentimentais no modo de se ajustarem às propriedades. Nem os senhores seriam capazes de imprimir rumo mais pessoal nos tratos de trabalho com gente que mantinham íntima cumplicidade, estreitando seus vínculos afetivos nas prosas intermináveis nas vendas, nos caminhos, nos momentos de trabalho, no filho que se batizava, no casamento que se apadrinhava (27).

Esses arranjos fluidos, bastante distanciados de qualquer pretensão em fixar-se em colônias, também eram bastante convenientes para a continuidade dessa vocação para o movimento, herança luso-brasileira dos tempos da colônia e que ao longo do tempo foram amalgamando-se às múltiplas esferas da vida. Mantinha-se, assim, a mobilidade necessária para a viabilização da sobrevivência material com negócios próprios, para empenhar-se em tarefas impossíveis de recusar em propriedade do compadre fazendeiro ou do vizinho e parente mais apertado em suas lides. Também permitiam ampla margem de tempo para o exercício das sociabilidades fundamentais.

Embora os senhores de café tenham expressado uma perturbadora inabilidade em lidar com relações de trabalho mais formais, Sérgio Buarque não deixou de 
reconhecer que "o mérito do sistema Vergueiro, com todos os vícios a que deu margem sua aplicação defeituosa, terá sido o de dar o primeiro exemplo do apelo em escala apreciável a trabalhadores livres na lavoura cafeeira", contribuindo para que alguns de seus traços dominantes se incorporassem em "caráter definitivo ao regime das fazendas... servindo para suavizar a transição entre a escravidão e o trabalho livre" (28).

O ensaio "Colônias de Parceria", portanto, vem frisar o compromisso de Sérgio Buarque com o estudo da civilização brasileira em todas as suas nuances e momentos históricos. De espírito inquieto, cada uma de suas obras parece conter a necessidade de experiências novas, apresentando caminhos inesgotáveis de pesquisa que têm propiciado às gerações atuais de historiadores imprimirem novos rumos às interpretações da nossa sociedade passada.

Em seus trabalhos Sérgio Buarque envolveu-se pelas vozes e pela sabedoria das pessoas comuns, admitindo que, para se “estudar o passado de um povo, de uma instituição, de uma classe, não basta aceitar ao pé da letra tudo quanto nos deixou a simples tradição escrita", sendo fundamental "fazer falar a multidão imensa dos figurantes mudos que enchem o panorama da história e são muitas vezes mais interessantes do que os outros, os que apenas escrevem a história", não esquecendo de ponderar, de espírito relativista que era, que este "exercício difícil e cheio de seduções perigosas onde faltam pontos de apoio seguros levará facilmente a aceitar seus resultados como a única verdade digna de respeito" (29).

Mesmo em obras e ensaios nos quais se enveredou pelos estudos de política e sociedade brasileira, tratando de mudanças socioeconômicas e eventos políticos, não deixou de aludir e abrir fendas que chegassem aos destinos desses "figurantes mudos" (30) e é nesse sentido que o ensaio “Colônias de Parceria” parece apontar novos vislumbres para o mundo cafeeiro das décadas finais da escravidão.
28 Sérgio Buarque de Holanda, "Colônias de Parceria", op. cit., pp. 255 e 260.

29 Idem, "Prefácio", op. cit., pp. 44-5.

30 Ver também e especialmente o capítulo "São Paulo", em História Geral da Civilização Brasileira (em colaboração comPedro Moacyr Campos).

O professor com seus alunos da

Faculdade de

Direito da

Universidade do

Brasil

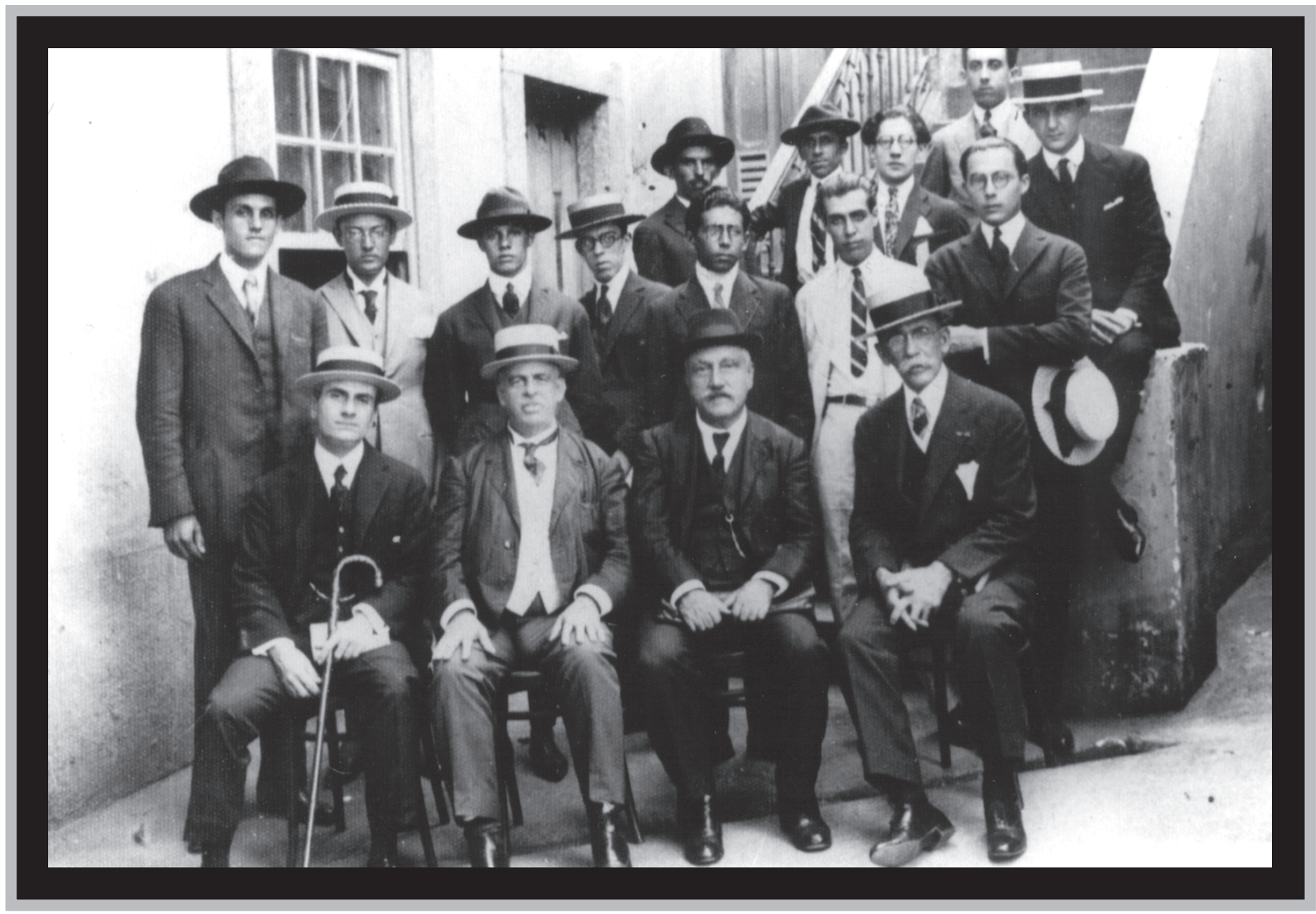

